\title{
Denitrification-Dependent Anaerobic Oxidation of Methane in Freshwater Sediments of Reservoirs in SE Poland
}

\author{
Dorota Szal ${ }^{* *}$, Renata Gruca-Rokosz' \\ 1 Rzeszów University of Technology, al. Powstańców Warszawy 12, 35-959 Rzeszów, Poland \\ * Corresponding author's e-mail: d.piwinska@prz.edu.pl
}

\begin{abstract}
The results presented here concern the anaerobic oxidation of methane $\left(\mathrm{CH}_{4}\right)$ coupled with denitrification (i.e. a process abbreviated to DAMO) in the freshwater sediments of dam reservoirs located in Rzeszów, Maziarnia and Nielisz, SE Poland. The DAMO rate was determined experimentally by adding a ${ }^{13} \mathrm{CH}_{4}$ isotope marker and $\mathrm{NO}_{3}^{-}$as an electron acceptor. The sediments were collected once, in autumn (September), with incubation of the $0-5,5-10$ and $10-15 \mathrm{~cm}$ layers then carried out at $10^{\circ} \mathrm{C}$, as the temperature corresponding to the in situ conditions at the given time of the year. The DAMO rates were set against the results for the anaerobic oxidation of methane (AOM), which were obtained by incubation of reservoir sediments with the ${ }^{13} \mathrm{CH}_{4}$ isotope marker alone. The DAMO rates noted were of $0.03-0.69 \mathrm{nmol} \cdot \mathrm{g}^{-1} \cdot \mathrm{h}^{-1}$ for Rzeszów Reservoir; $0.04-0.47 \mathrm{nmol} \cdot \mathrm{g}^{-1} \cdot \mathrm{h}^{-1}$ for Maziarnia Reservoir and $0.19-1.04 \mathrm{nmol} \cdot \mathrm{g}^{-1} \cdot \mathrm{h}^{-1}$ for Nielisz Reservoir. Overall, it was typical for the DAMO rates to be about twice as high as the rates of $\mathrm{AOM}$ with no electron acceptor added. The addition of $\mathrm{NO}_{3}^{-}$did not accelerate the methane oxidation significantly in any of the sediment layers from Maziarnia Reservoir, while the effects in Rzeszów Reservoir sediments were confined to the $10-15 \mathrm{~cm}$ layer. While the DAMO rates were progressively higher in the deeper layers of sediment from Maziarnia Reservoir, the trend was the reverse (downward) with depth at the Rzeszów and Nielisz sites. The results indicate that the process abbreviated as DAMO takes place in dam reservoirs and is related, not only to the presence of $\mathrm{NO}_{3}^{-}$, but also to the sediment parameters.
\end{abstract}

Keywords: denitrification-dependent anaerobic oxidation of methane, electron acceptors, sediment incubation experiment

\section{INTRODUCTION}

Higher global temperatures are capable of causing massive releases of methane gas $\left(\mathrm{CH}_{4}\right)$ to the atmosphere, from both marine and freshwater ecosystems, with the potential effect of that being a further aggravation and progression of the climate change. One of the key processes regulating the flows of $\mathrm{CH}_{4}$ into the atmosphere is the anaerobic oxidation of methane (abbreviated to $\mathrm{AOM}$ ) - which is considered responsible for a reduction of $7-25 \%$ of the global $\mathrm{CH}_{4}$ production per year [Knittel and Boetius 2009; Hou et al. 2017]. AOM proceeds in line with the reduction of various electron acceptors, including sulphates, nitrites, nitrates and metals. AOM, coupled with the reduction of $\mathrm{NO}_{3}{ }^{-} / \mathrm{NO}_{2}{ }^{-}$ions (known as anaerobic oxidation of methane combined with denitrification, or DAMO), exerts a simultaneous impact on the key global cycles involving carbon and nitrogen, while reducing the emissions of $\mathrm{CH}_{4}$ and $\mathrm{N}_{2} \mathrm{O}$ in line with the reaction [Hou et al. 2017; Weiwei et al. 2018]:

$$
\begin{aligned}
& 5 \mathrm{CH}_{4}+8 \mathrm{NO}_{3}^{-}+8 \mathrm{H}^{+} \rightarrow 5 \mathrm{CO}_{2}+4 \mathrm{~N}_{2}+14 \mathrm{H}_{2} \mathrm{O} \\
& 3 \mathrm{CH}_{4}+8 \mathrm{NO}_{2}^{-}+8 \mathrm{H}^{+} \rightarrow 3 \mathrm{CO}_{2}+4 \mathrm{~N}_{2}+10 \mathrm{H}_{2} \mathrm{O}
\end{aligned}
$$

The evidence for the presence of DAMO in freshwater ecosystems first appeared in 2004 [Islas-Lima et al. 2004], and first laboratory-scale research was carried out in 2006 [Raghoebarsing et al. 2006]. Until recently, the DAMO process in freshwater sediments was not given much consideration due to the limited availability of $\mathrm{NO}_{3}^{-}$(a consequence of either excessively slow nitrification or excessively rapid denitrification). 
However, the research carried out worldwide has demonstrated the process occurring in such freshwater ecosystems as boreal lakes [Norði and Thamdrup 2014], Lake Constance [Deutzmann et al. 2014] or wetlands [Hu et al. 2014]. Hu et al. [2014] estimated that about $2-6 \%$ of current global $\mathrm{CH}_{4}$ production is the result of the oxidation reactions taking place in wetlands [Bhattacharjee et al. 2016, Chen et al. 2014, Hu et al. 2014, Liping et al. 2018, Ru et al. 2017].

Since the available literature has very little data on the above-mentioned process as it occurs in the sediments of dam reservoirs, this paper presents the research on DAMO in the sediments of Rzeszów, Maziarnia and Nielisz Reservoirs all located in SE Poland. The said research saw the sediments incubated at the authentic in-situ temperature, along with a ${ }^{13} \mathrm{CH}_{4}$ isotope marker and $\mathrm{NO}_{3}^{-}$as an electron acceptor, with a view to determining the rate of any DAMO reaction taking place.

\section{MATERIALS AND METHODS}

\section{Study area}

The researched Rzeszów and Maziarnia Reservoirs are located in SE Poland's Podkarpackie Voivodship (Province-Region), while Nielisz Reservoir is in Lubelskie Voivodship. Completed in 1974, Rzeszów Reservoir involved the damming of the Wisłok some $64 \mathrm{~km}$ along its course. The other tributary feeding this body of water is Strug. While the main purpose of the reservoir construction was the proper operation of a water intake for the city of Rzeszów, the body of water in question also has an important sporting and recreational role to play. A proportionally large reduction in the overall volume (of $0.7 \mathrm{M} \mathrm{m}^{3}$ ) has affected the Reservoir over the last 40 years, with many areas (in the upper part especially) silted up and gradually transforming into land. The catchment area in this case is of $2050 \mathrm{~km}^{2}$, while the Reservoir's immediate surroundings include wasteland, arable fields and a few scattered buildings. Away from several industrial centers, there is a predominantly agricultural area [Koszelnik and Tomaszek 2002; Gruca-Rokosz 2015].

Maziarnia Reservoir is also a dam reservoir, in this case along the River Łęg, the catchment of which in its upper part features podsolic soils, while the valley bottom is covered by sandy muds and formations reflecting the river accumulation. Another part of the catchment area is covered with soils arising out of loose sands, or else lightly loamy or loamy sands. Given the lack of industrial centers in the vicinity, the catchment of the Łęg is only polluted by domestic sewage and the surface runoff from agricultural areas. While this Reservoir was originally to meet the needs of local waterworks, irrigation and farms with ponds, it today has a retention function, above all [Gruca-Rokosz 2015].

The Nielisz dam reservoir is situated along the middle course of the River Wieprz. Surrounded by a strip of coniferous forest, it consists of a main reservoir and a primary reservoir. There is a $362 \mathrm{~kW}$ hydropower plant on the dam. The main purposes of this body of water are thus protection against flooding, as well as energy production, $\mathrm{R} \& \mathrm{R}$ and amateur angling.

The reservoir sediments were sampled at a station located near the dam (of Rzeszów Reservoir) or else near the tributary (Maziarnia and Nielisz Reservoirs), in the light of recent studies indicating that the $\mathrm{CH}_{4}$ emissions there might be considerable, at $29.13 \pm 67.87 \mathrm{mmol} \cdot \mathrm{m}^{-2} \cdot \mathrm{d}^{-1}$ (Rzeszów), $372.43 \pm 328.75 \mathrm{mmol} \cdot \mathrm{m}^{-2} \cdot \mathrm{d}^{-1}$ (Maziarnia) and $209.55 \pm 155.13 \mathrm{mmol} \cdot \mathrm{m}^{-2} \cdot \mathrm{d}^{-1}$ (Nielisz), on average [Gruca-Rokosz 2015].

The locations of the Rzeszów, Maziarnia and Nielisz Reservoirs and the sampling stations are shown in Figure 1.

\section{Sediment sampling and preparation}

The reservoir sediments collected in autumn (September) 2018 were found to be at a temperature of $10^{\circ} \mathrm{C}$. Five cores were in fact taken, using a specially-designed sediment corer (No. P.428513), and immediately transported to the laboratory, along with the overlying water. The sediment cores were then pushed progressively from the bottom of Plexiglas tubes by a piston, in such a way that it was possible to study separately the layers present at depths of $0-5$, 5-10 and $10-15 \mathrm{~cm}$.

The pore-water was centrifuged from three layers of one core in a laboratory centrifuge (MPW-352), so that determinations could be made for organic carbon (TOC), as well as nitrite, nitrate and sulphate ions $\left(\mathrm{NO}_{2}^{-}, \mathrm{NO}_{3}^{-}\right.$and $\left.\mathrm{SO}_{4}{ }^{2-}\right)$. The pore-water from a second core was squeezed directly into a gastight vial using a modified porewater squeezer (Reeburgh 1967), in order for 


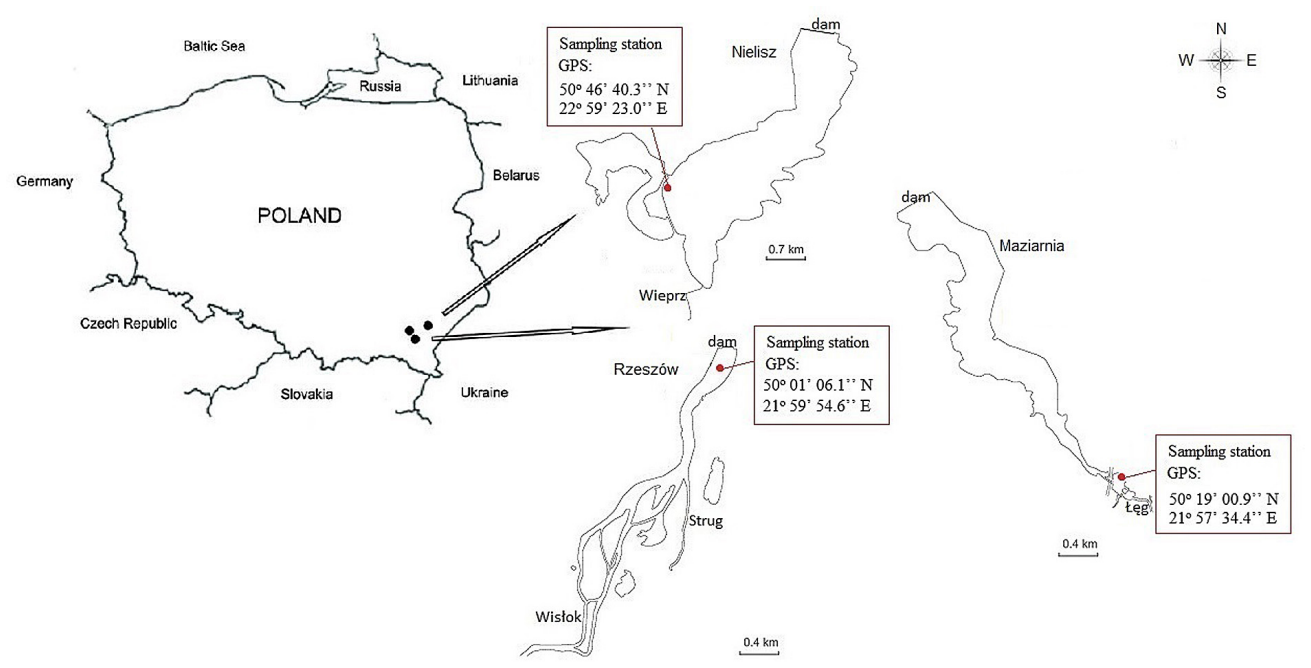

Fig. 1. Location of Rzeszów, Maziarnia and Nielisz Reservoirs, and the sampling stations

contact with the atmosphere to be avoided, so that a determination for trivalent iron $\left(\mathrm{Fe}^{3+}\right)$ could be carried out.

The three sediment layers from the third core were dried to constant weight at room temperature, and subsequently at $60{ }^{\circ} \mathrm{C}$, before the sediments were milled prior to determining parameters like $\mathrm{pH}$, organic matter $(\mathrm{OM})$, total organic carbon (TOC), total nitrogen (TN) and humic substances (HS).

The sediments from the fourth and fifth cores were used to research the process of the anaerobic oxidation of methane (AOM).

\section{Incubation experiment}

In the experiment, $7 \mathrm{~g}$ of wet sediment from each layer was placed into a gastight incubation vessel with $14 \mathrm{~mL}$ of distilled water deoxygenated by nitrogen purging (99.99\% Air Products) using a laboratory scrubber [Gupta 2011]. All operations were carried out in a glove box (830ABB Compact Glove Box Plas-Labs, Inc. USA). Prior to the laboratory work, the air in the glove box was replaced with helium $(99.9999 \%$ Air Products), 7-8 times. The prepared samples were then subjected to pre-incubation by placing them in the dark in a thermostat for 10 days at in-situ temperature $\left(10^{\circ} \mathrm{C}-\right.$ autumn $)$, to allow for the removal of residual oxygen by microorganisms, via biochemical processes. It was only after this that the ${ }^{13} \mathrm{CH}_{4}$ isotope marker (99\%, Sigma-Aldrich 490229-1L-EU) - and in the incubations with the addition of electron acceptor $\mathrm{NO}_{3}{ }^{-}$ $1 \mathrm{ml}$ of $\mathrm{Ca}\left(\mathrm{NO}_{3}\right)_{2} \cdot \mathrm{H}_{2} \mathrm{O}$ at concentration of $\mathrm{NO}_{3}^{-}$ $2.1 \mathrm{mmol} \cdot 1^{-1}$ - were added to appropriate samples, so that the final concentration in the samples was $100 \mu \mathrm{mol} \cdot \mathrm{l}^{-1}$. The incubations were carried out at a temperature corresponding to the in-situ sediment temperature in autumn $\left(10{ }^{\circ} \mathrm{C}\right)$. After a certain time (incubation times of $0,3,10,20,30,40$ and 50 days), $1 \mathrm{~cm}^{3}$ of the headspace was withdrawn using a gastight syringe (1001SL Hamilton) and analyzed for the $\mathrm{CO}_{2}$ concentrations (ppm) using a Shimadzu GC-2010 Plus gas chromatograph equipped with a Barrier Discharge Ionization Detector (BID) and a Shin Carbon ST column (2 m, $1.00 \mathrm{~mm}$ ID, Mesh 100/120). The samples were injected manually into a GC apparatus with the detector working at $250^{\circ} \mathrm{C}$. The temperatures were $150^{\circ} \mathrm{C}$ for the injection port and $60^{\circ} \mathrm{C}$ for the column (the latter being maintained for 13 minutes). The carrier gas was helium (99.9999\% Air Products) at a $50 \mathrm{ml} \cdot \mathrm{min}^{-1}$ flow rate. The carbon isotopic composition of $\mathrm{CO}_{2}$ was determined using gas chromatograph combustion isotope mass spectrometry (GC-CIII-IRMS DELTA ${ }^{\text {Plus }}$ Finnigan), by withdrawing $0.1 \mathrm{~cm}^{3}$ of the headspace using a syringe (1700, Hamilton). The results of stable isotope analyses are presented in the form of $\delta^{13} \mathrm{C}$ expressed in [\%] relative to the PDB (Pee Dee Belemnite) standard (Eq. 1):

$$
\delta^{13} C=\left({ }^{13} C /{ }^{12} C_{(\text {sample })}\right) /\left({ }^{13} C /{ }^{12} C_{(\text {std })}-1\right) 1000 .
$$

The results obtained for the $\mathrm{CO}_{2}$ concentrations (ppm) and $\delta^{13} \mathrm{C}-\mathrm{CO}_{2}(\%)$ were used to calculate the rate at which the anaerobic oxidation of methane had taken place. The $\mathrm{CO}_{2}$ concentration at time "zero" was subtracted from each $\mathrm{CO}_{2}$ concentration measured after $3,10,20,30,40$ and 50 days of incubation. 


\section{Sediment and pore-water analysis}

The reaction was determined potentiometrically (MultiLine P4, WTW, Germany) in slurry with $1 \mathrm{~N} \mathrm{KCl}$ [Ostrowska et al. 1991]. The OM content was determined as the loss after drying of sediments within $4 \mathrm{~h}$ at $550^{\circ} \mathrm{C}$ [Holmer et al. 2005]. The contents of TOC and TN were determined at $1020^{\circ} \mathrm{C}$ using a $\mathrm{CN}$ elemental analyzer (Flash EA 1112, ThermoQuest). The quality analysis made use of the standard samples of known amounts of carbon and nitrogen (acetanilide). Prior to the determination of the TOC content, the dried and ground sediment samples were placed in a desiccator with concentrated $\mathrm{HCl}$ vapor [Zimmermann et al. 1997] for $72 \mathrm{~h}$, to ensure the removal of carbonates. Prior to the analysis, the sediment sample was again dried to constant weight at $60^{\circ} \mathrm{C}$. The modified method of Griffith and Schnitzer (1975) was used in determining the content of humic substances (HS). The procedure for the determination of the HS is described in detail in Bartoszek [2019].

Ions - i.e. nitrite $\left(\mathrm{NO}_{2}^{-}\right)$, nitrate $\left(\mathrm{NO}_{3}^{-}\right)$and sulphate $\left(\mathrm{SO}_{4}^{2-}\right)$ - were analysed in pore-water after first being centrifuged and filtered through $0.22 \mu \mathrm{m}$ syringe filters using DIONEX ICS-5000 ion chromatography. Total organic carbon was determined using a Shimadzu TOC-V CPN Total Organic Carbon Analyzer, while the concentration of $\mathrm{Fe}^{3+}$ was determined spectrophotometrically using ferrozine, after Viollier et al. [2000]. Absorbance was measured using a Hach UV-VIS spectrometer at $562 \mathrm{~nm}$.

\section{Calculations}

The AOM and DAMO rates $\left(\mathrm{nmol} \cdot \mathrm{g}^{-1} \cdot \mathrm{h}^{-1}\right)$ and the amount of $\mathrm{CH}_{4}$ oxidised ( $\mathrm{nmol} \cdot \mathrm{g}^{-1}$ ) were calculated using a formula developed by reference to the available literature [Gupta 2011; Shi et al. 2017]
(2) and (3). $\delta^{13} \mathrm{C}-\mathrm{CO}_{2}$ was converted to ${ }^{13} \mathrm{C}$ atom percent $\left({ }^{13} \mathrm{C} \mathrm{AT} \%\right)$ in line with Eq. (4):

$$
\begin{gathered}
A O M / D A M O\left(\text { nmol } g^{-1} h^{-1}\right)= \\
\left(\frac{{ }^{13} C A T \%}{100} \cdot\left[C O_{2}\right](\text { ppm }) \cdot\right. \\
\left.\left(V_{g}\left(d m^{3}\right) / V_{m}\left(\frac{d m^{3}}{m o l}\right)\right) \cdot 1000\right) /(m(g) \cdot t(h)) \\
C H_{4} \text { oxidised }\left(\text { nmol } g^{-1}\right)=A O M \cdot t(h) \\
{ }^{13} C A T=\left(\delta^{13} C P D B+1000 / \delta^{13} C P D B+1000+\frac{1000}{R_{s t d}}\right) \cdot 100= \\
\left.\left({ }^{13} \mathrm{Co}_{2}\right] \int\left[{ }^{13} \mathrm{CO}_{2}\right]+\left[{ }^{12} \mathrm{co} \mathrm{O}_{2}\right]\right) \cdot 100=\left(\left[{ }^{13} \mathrm{co}_{2}\right] /\left[C \mathrm{CO}_{2}\right]\right) \cdot 100
\end{gathered}
$$

where ${ }^{13} \mathrm{C} A T-{ }^{13} \mathrm{C}$ atom percent (\%); $\mathrm{CO}_{2}$ - carbon dioxide concentration at time t (ppm);

$V_{g^{-}}$volume of headspace in vial $\left(0.096156 \mathrm{dm}^{3}\right)$;

$V_{m}$ - molar volume of ideal gas at $25^{\circ} \mathrm{C}$ $\left(24.45 \mathrm{dm}^{3} \cdot \mathrm{mol}^{-1}\right)$; $\mathrm{m}$ - dry sediment weight $(\mathrm{g})$; $t$ - incubation time (h);

$R_{\text {std }}$ - absolute ratio constants in the standard (0.0111803).

\section{RESULTS}

\section{Characteristics of sediments and pore water}

\section{Sediment characteristics}

The results for selected chemical parameters characterising the sediments of Rzeszów,

\begin{tabular}{|c|c|c|c|c|c|c|c|c|c|c|}
\hline \multirow{3}{*}{ Parameter } & \multirow{3}{*}{ Unit } & \multicolumn{3}{|c|}{ Rzeszów } & \multicolumn{3}{|c|}{ Maziarnia } & \multicolumn{3}{|c|}{ Nielisz } \\
\hline & & \multicolumn{9}{|c|}{ Sediment layer [cm] } \\
\hline & & $0-5$ & $5-10$ & $10-15$ & $0-5$ & $5-10$ & $10-15$ & $0-5$ & $5-10$ & $10-15$ \\
\hline $\mathrm{pH}$ & - & 7.20 & 7.20 & 7.39 & 6.55 & 5.95 & 5.57 & 7.21 & 7.26 & 7.25 \\
\hline OM & \multirow{3}{*}{$\%$} & 10.84 & 9.09 & 6.46 & 8.19 & 8.03 & 3.27 & 11.19 & 12.31 & 13.42 \\
\hline TOC & & 3.62 & 2.89 & 1.82 & 2.96 & 3.14 & 0.89 & 4.17 & 5.15 & 5.51 \\
\hline TN & & 0.37 & 0.27 & 0.17 & 0.27 & 0.28 & 0.08 & 0.42 & 0.50 & 0.54 \\
\hline C:N & - & 9.86 & 10.69 & 10.81 & 10.92 & 11.05 & 11.07 & 9.83 & 10.40 & 10.14 \\
\hline HS & $\mathrm{mg} \cdot \mathrm{g}^{-1} \mathrm{~d} \cdot \mathrm{w}$. & 31.7 & 27.5 & 17.6 & 27.3 & 30.7 & 9.0 & 34.8 & 42.3 & 47.8 \\
\hline
\end{tabular}
Maziarnia and Nielisz Reservoirs are summarised in Table 1.

The reactions of the Rzeszów and Nielisz Reservoir sediments were slightly alkaline, with

Table 1. Selected chemical parameters characterising the reservoir sediments 
the $\mathrm{pH}$ values varying across the narrow ranges 7.20-7.39 (Rzeszów) and 7.21-7.26 (Nielisz). The sediments of Maziarnia Reservoir had much lower $\mathrm{pH}$ values, in the 5.57-6.55 range.

The contents of organic matter (OM) in the reservoir sediments ranged from 3.27 to $13.42 \%$. The highest values were noted for the Nielisz sediments, as followed by those from the Rzeszów site. The average content of organic matter was greater than $8 \%$, but the highest value did not exceed $11 \%$. It was typical to note lower OM contents at greater depths in sediments, and in Rzeszów and Maziarnia Reservoirs, this depletion assumed certain significance, with the $10-15 \mathrm{~cm}$ layer depleted by about $5 \%$ in comparison with the surface layer. In contrast, the sediment profile at Nielisz Reservoir was characterised by higher OM contents in deeper layers.

The content of organic carbon (TOC) in the uppermost sediment layer varied across a $0.89-5.51 \%$ range. The tendencies for TOC analogous to those for $\mathrm{OM}$ were observed in all cases. The highest TOC content was obtained in the sediments sampled from Nielisz Reservoir. At all sites, organic carbon accounted for about $30 \%$ of values for OM.

As with OM and TOC, it was sediments from Nielisz Reservoir that had highest values for total nitrogen (TN) content. The lowest values, in turn, characterised the sediments sampled from Maziarnia Reservoir. All observed trends for the changes in $\mathrm{TN}$ were analogous to those noted for $\mathrm{OM}$ and TOC.

In Rzeszów Reservoir, the $\mathrm{C}: \mathrm{N}$ ratios down the sediment profile were in the 9.86-15.26 range, with slight depth-related change. Similar values were obtained for the sediments from the other reservoirs, with the $\mathrm{C}: \mathrm{N}$ ratios of 10.92-11.07 (Maziarnia) and 9.83-10.40 (Nielisz). Lower $\mathrm{C}: \mathrm{N}$ ratios recorded for the $0-5 \mathrm{~cm}$ layer point to a greater share of autochthonous matter. In turn, organic matter in the $10-15 \mathrm{~cm}$ sediment layer is mainly of allochthonous origin, with sources taken to include macrophytes and plants rich in cellulose [Gruca-Rokosz 2015].

The content of humic substances in the sediments ranged from 9.0 to $47.8 \mathrm{mg} \cdot \mathrm{g}^{-1} \mathrm{~d}$.w. In all cases, the tendencies were analogous to those observed for the parameters referred to above (OM, TOC and TN), with the highest values again noted for the sediments from Nielisz Reservoir.

\section{Pore-water characteristics}

The values for pore-water concentrations of the $\mathrm{NO}_{2}^{-}, \mathrm{NO}_{3}^{-}, \mathrm{SO}_{4}^{2-}$ and $\mathrm{Fe}^{3+}$ ions are as shown in Table 2.

Comparable $\mathrm{NO}_{2}^{-}$and $\mathrm{NO}_{3}^{-}$concentrations were obtained for all dam reservoirs, with values in the ranges $0.01-0.02$ and $0.02-0.03 \mathrm{mg} \cdot \mathrm{dm}^{-3}$, respectively. In the case of sulphate ions, the ranges differed from one reservoir to another. The lowest concentrations characterised Rzeszów Reservoir $\left(0.04-0.23 \mathrm{mg} \cdot \mathrm{dm}^{-3}\right)$, while the values on average three or more than ten times as high noted for Nielisz and Maziarnia Reservoirs, respectively. The $\mathrm{Fe}^{3+}$ concentrations varied from $95.40 \mu \mathrm{mol} \cdot \mathrm{dm}^{-3}$ (Rzeszów) to $580.66 \mu \mathrm{mol} \cdot \mathrm{dm}^{-3}$ (Nielisz).

\section{Rates of anaerobic oxidation of methane}

All sediments sampled for the purposes of the research proved capable of oxidising methane under anaerobic conditions. The $\mathrm{CO}_{2}$ enrichment with the ${ }^{13} \mathrm{C}$ isotope was noted in the headspace, indicating oxidation of the ${ }^{13} \mathrm{CH}_{4}$ isotope marker added. A value for the ${ }^{13} \mathrm{C}$ atom percent $\left({ }^{13} \mathrm{C} \mathrm{AT} \%\right)$ was arrived at by calculation, using $\delta^{13} \mathrm{C}-\mathrm{CO}_{2}(\%)$ readings obtained for the headspace in the course of incubation, and the results are shown graphically in Fig. 2.

During the experiment, the ${ }^{13} \mathrm{C} \mathrm{AP}$ values ranged from 1.31 to $37.22 \%$, and from 1.38 to $46.68 \%$, in incubations carried out in the presence of ${ }^{13} \mathrm{CH}_{4}$ or ${ }^{13} \mathrm{CH}_{4}+\mathrm{NO}_{3}^{-}$, respectively. A steady increase in the concentrations of $\mathrm{CO}_{2}$ in

Table 2. Results for chemical parameters of pore-water in reservoir sediments

\begin{tabular}{|c|c|c|c|c|c|c|c|c|c|c|}
\hline \multirow{3}{*}{ Parameter } & \multirow{3}{*}{ Unit } & \multicolumn{3}{|c|}{ Rzeszów } & \multicolumn{3}{|c|}{ Maziarnia } & \multicolumn{3}{|c|}{ Nielisz } \\
\hline & & \multicolumn{9}{|c|}{ Sediment layer $[\mathrm{cm}]$} \\
\hline & & $0-5$ & $5-10$ & $10-15$ & $0-5$ & $5-10$ & $10-15$ & $0-5$ & $5-10$ & $10-15$ \\
\hline $\mathrm{NO}_{2}^{-}$ & \multirow{3}{*}{$\mathrm{mg} \cdot \mathrm{dm}^{-3}$} & 0.02 & 0.01 & 0.02 & 0.01 & n.d. & n.d. & 0.01 & 0.01 & 0.01 \\
\hline $\mathrm{NO}_{3}^{-}$ & & 0.02 & 0.02 & 0.02 & 0.02 & 0.02 & 0.03 & 0.03 & 0.02 & 0.02 \\
\hline $\mathrm{SO}_{4}{ }^{2-}$ & & 0.23 & 0.04 & n.d. & 5.32 & 1.05 & 0.84 & 0.77 & 0.26 & 0.24 \\
\hline $\mathrm{Fe}^{3+}$ & $\mu \mathrm{mol} \cdot \mathrm{dm}^{-3}$ & 380.57 & 182.80 & 95.40 & 495.44 & 384.84 & 190.04 & 580.66 & 313.25 & 271.47 \\
\hline
\end{tabular}


a) $0-5 \mathrm{~cm} ;{ }^{13} \mathrm{CH}_{4}$

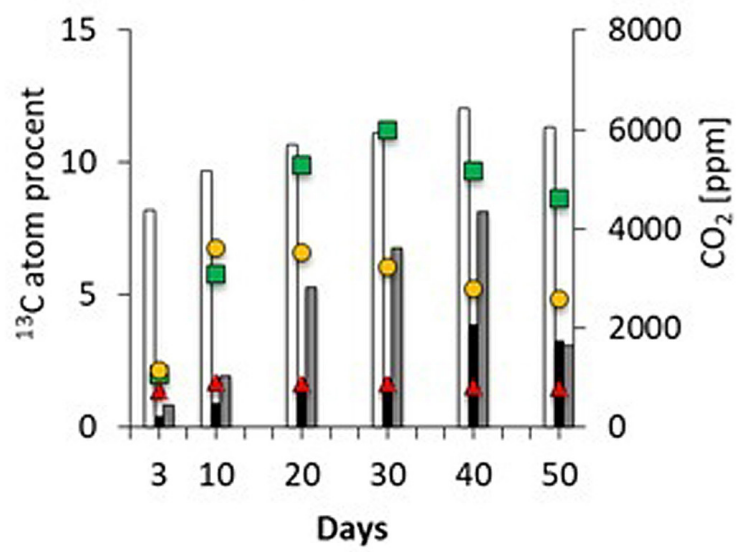

c) $5-10 \mathrm{~cm} ;{ }^{13} \mathrm{CH}_{4}$

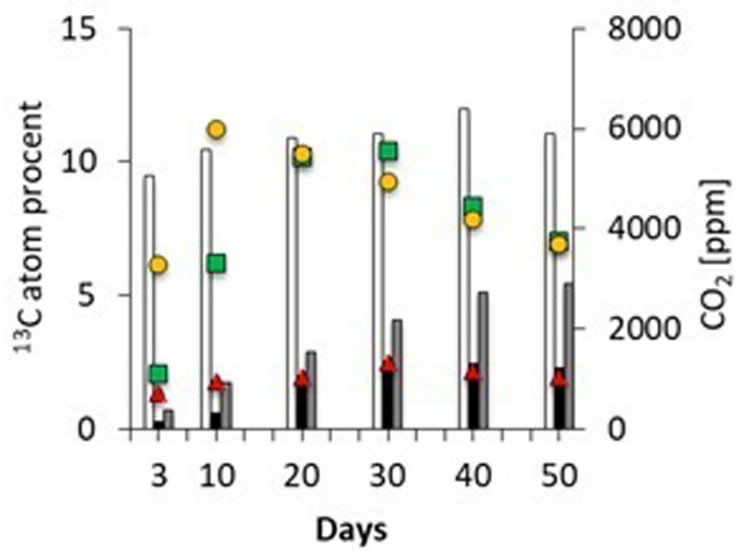

e) $10-15 \mathrm{~cm} ;{ }^{13} \mathrm{CH}_{4}$

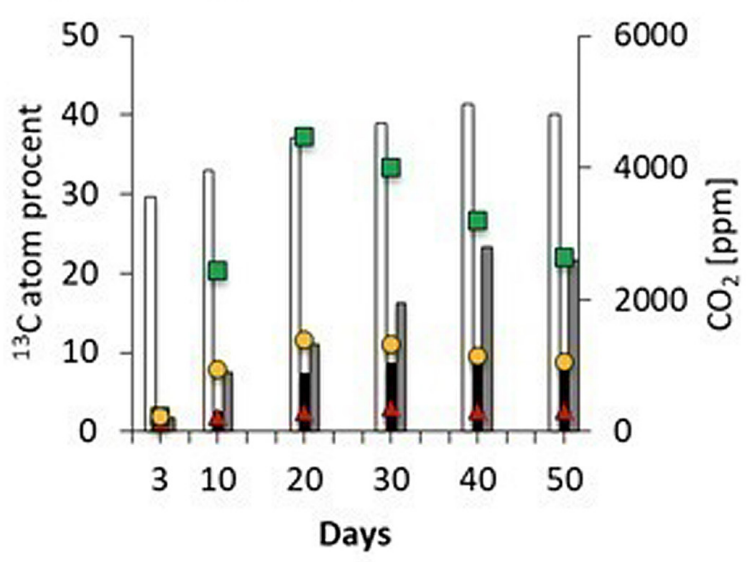

b) $0-5 \mathrm{~cm} ;{ }^{13} \mathrm{CH}_{4}+\mathrm{NO}_{3}{ }^{-}$

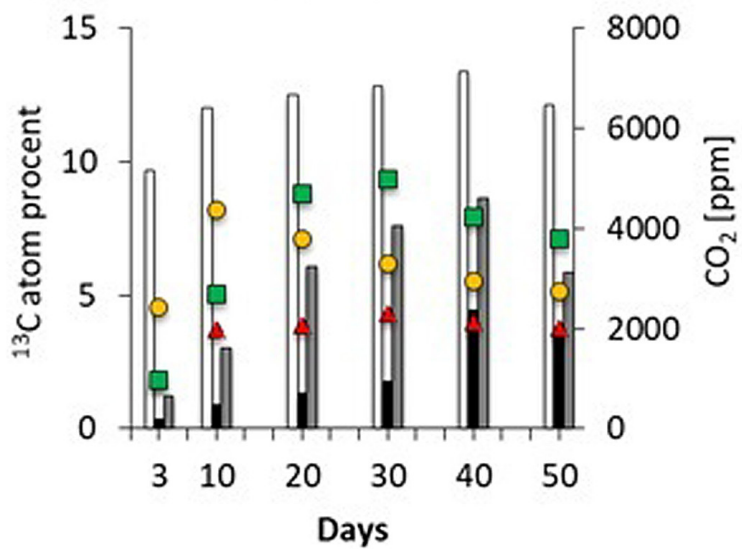

d) $5-10 \mathrm{~cm} ;{ }^{13} \mathrm{CH}_{4}+\mathrm{NO}_{3}{ }^{-}$

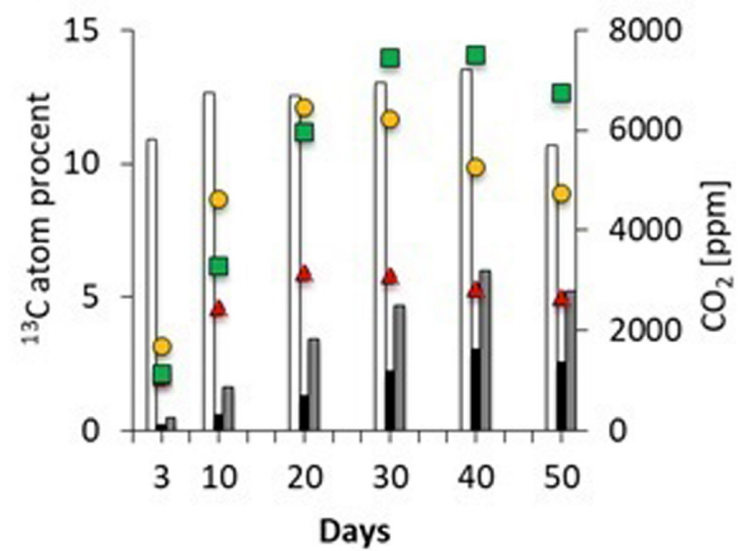

f) $10-15 \mathrm{~cm} ;{ }^{13} \mathrm{CH}_{4}+\mathrm{NO}_{3}^{-}$

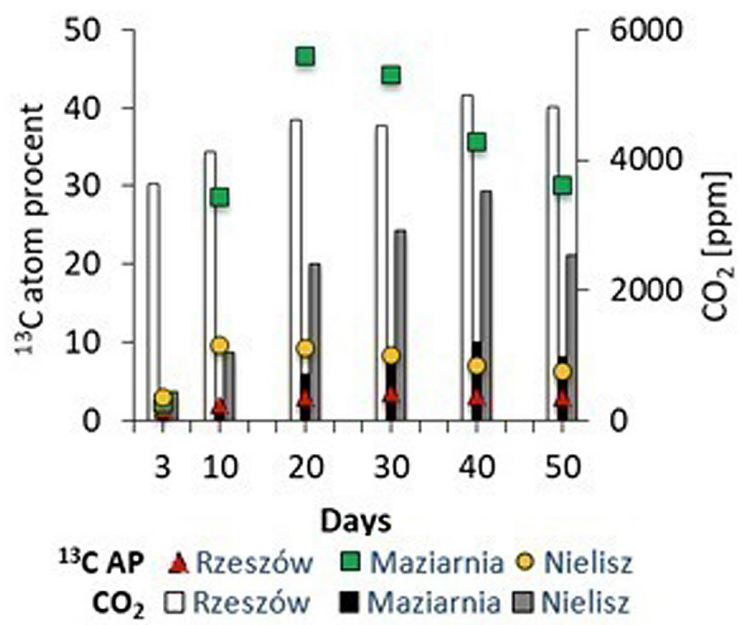

Fig. 2. Change of ${ }^{13} \mathrm{C}$ AP and $\mathrm{CO}_{2}$ over time for incubations conducted with the addition of ${ }^{13} \mathrm{CH}_{4}$ (panel a, c, e) or ${ }^{13} \mathrm{CH}_{4}+\mathrm{NO}_{3}^{-}$(panel b, d, f) 
the headspace was noted up to day 40 (with ${ }^{13} \mathrm{CH}_{4}$ and ${ }^{13} \mathrm{CH}_{4}+\mathrm{NO}_{3}^{-}$). However, incubation with added $\mathrm{NO}_{3}^{-}$gave rise to maximum $\mathrm{CO}_{2}$ concentrations of $7300 \mathrm{ppm}$, as opposed to $6500 \mathrm{ppm}$ where incubation was with the ${ }^{13} \mathrm{CH}_{4}$ marker alone.

The rates of anaerobic oxidation of methane with or without added $\mathrm{NO}_{3}{ }^{-}$are shown graphically in Figure 3, along with the amounts of $\mathrm{CH}_{4}$ oxidised. The anaerobic oxidation of methane proved most effective in the sediments (of all layers) sampled from Nielisz Reservoir, in both incubations with ${ }^{13} \mathrm{CH}_{4}$ and ${ }^{13} \mathrm{CH}_{4}+\mathrm{NO}_{3}^{-}$. The rates were lower in the sediments from Rzeszów $\left({ }^{13} \mathrm{CH}_{4}\right)$ and Maziarnia $\left({ }^{13} \mathrm{CH}_{4}+\mathrm{NO}_{3}^{-}\right)$. The rates for the process taking place under both types of incubation and with sediments from all reservoirs usually peaked on day 20. However, at that time (with ${ }^{13} \mathrm{CH}_{4}+\mathrm{NO}_{3}^{-}$), the figure obtained for Nielisz Reservoir was three times as high on average as the ones noted for Rzeszów and Maziarnia.

Where the amounts of methane oxidised were concerned, the peak values for sediments from all reservoirs were reached on day 40 of incubation (with either ${ }^{13} \mathrm{CH}_{4}$ or ${ }^{13} \mathrm{CH}_{4}+\mathrm{NO}_{3}^{-}$). Thus, the amount of $\mathrm{CH}_{4}$ oxidised had actually decreased by the last day of the research (day 50). For the incubation with added ${ }^{13} \mathrm{CH}_{4}+\mathrm{NO}_{3}^{-}$the amounts of $\mathrm{CH}_{4}$ oxidised on day 40 were almost $250 \mathrm{nmol} \cdot \mathrm{g}^{-1}$ (Rzeszów), $300 \mathrm{nmol} \cdot \mathrm{g}^{-1}$ (Maziarnia) and $600 \mathrm{nmol} \cdot \mathrm{g}^{-1}$ (Nielisz). In the case of incubation with the ${ }^{13} \mathrm{CH}_{4}$ isotope marker alone, the amounts of $\mathrm{CH}_{4}$ oxidised (after 40 days) did not exceed $90 \mathrm{nmol} \cdot \mathrm{g}^{-1}$ in the Rzeszów sediments, while the values for Maziarnia Reservoir remained below $300 \mathrm{nmol} \cdot \mathrm{g}^{-1}$, compared with those for Nielisz reaching $400 \mathrm{nmol} \cdot \mathrm{g}^{-1}$.

\section{DISCUSSION}

The research reported here confirms the presence of the DAMO (denitrifying anaerobic methane oxidation) process in the freshwater sediments from certain dam reservoirs in Poland. ${ }^{13} \mathrm{CO}_{2}$ was present in the headspace as all sediment samples were incubated, denoting an origin in the oxidation of the ${ }^{13} \mathrm{CH}_{4}$ with which the sediments were dosed. The AOM rate in the incubations carried out with the isotope marker alone was in most cases significantly lower than where $\mathrm{NO}_{3}{ }^{-}$was also added. Slight departures were observed in just two cases of the $10-15 \mathrm{~cm}$ layer of sediment from Rzeszów Reservoir and the 0-5 $\mathrm{cm}$ layer from Maziarnia. Such results point to a significant impact of nitrate on the dynamics of methane's anaerobic oxidation.

Out of the sediments sampled, the most and least rich in organic matter (including TOC and TN) were those from Nielisz and Maziarnia Reservoirs, respectively. The rates of the anaerobic oxidation of methane were highest in Nielisz sediments, and lowest in those from Maziarnia Reservoir. Additionally, as statistically significant correlations between the rate of DAMO and OM, TOC and TN were obtained $\left(\mathrm{R}^{2}=0.65\right)$, it may be the availability of $\mathrm{C}$ and $\mathrm{N}$ that determine whether or not DAMO takes place in the sediments of dam reservoirs.

The DAMO rates in Maziarnia Reservoir sediments were the subject of an upward trend with layer depth, though the reverse relationship applied to the Rzeszów and Nielisz sites. While anaerobic oxidation may be occurring, $\mathrm{CH}_{4}$ is also being produced, in the amounts that become significant in deeper sediment layers in particular. Methanogenesis entails the decomposition of "old" carbon in deeper layers of sediment, with some of the carbon then available for anaerobic oxidation in the presence of alternative electron acceptors. In addition, the $\mathrm{CH}_{4}$ produced in deeper sediment layers begins to diffuse upwards, to areas near the sediment-water interface where electron acceptors are increasingly available [Smemo and Yavitt 2007; Broman E. 2013].

The reported DAMO rate usually peaked on day 20. The subsequent decrease may reflect the gradual depletion of $\mathrm{NO}_{3}^{-}$over time [Fan et al. 2019]. Furthermore, by the 50th day of the research there had actually been a decrease in the amount of methane oxidized compared with the previous situation, denoting the increased relative importance of the methane production process probably occurring simultaneously throughout the trial, but proving less tangible earlier on.

Other researchers [Shi et al. 2017] have likewise determined the amounts of methane oxidised in sediments under anaerobic conditions. On day 3 of incubation, these ranged from 97.08 to $143.69 \mathrm{nmol} \cdot \mathrm{g}^{-1}$. Our values closest to this range were obtained in the $0-5 \mathrm{~cm}$ layer of sediment from Nielisz Reservoir (on day 3). On average, the values only one-fifth as high were obtained for other layers and other reservoirs analysed.

The literature offers very little information on the DAMO rates in freshwater ecosystems, and no data whatever for dam reservoirs. Most 
a) $0-5 \mathrm{~cm} ;{ }^{13} \mathrm{CH}_{4}$

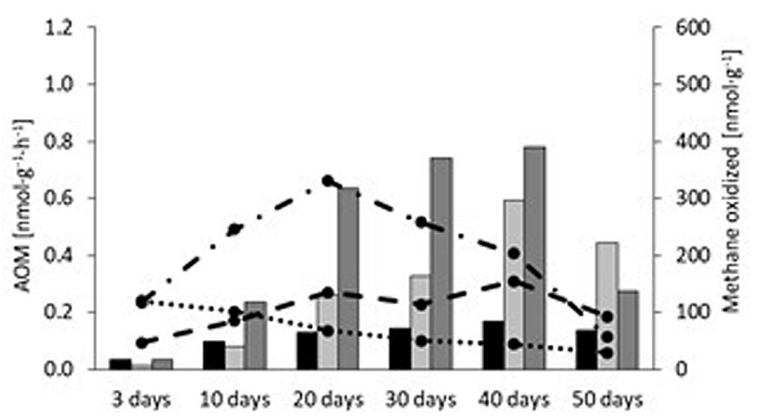

c) $5-10 \mathrm{~cm} ;{ }^{13} \mathrm{CH}_{4}$

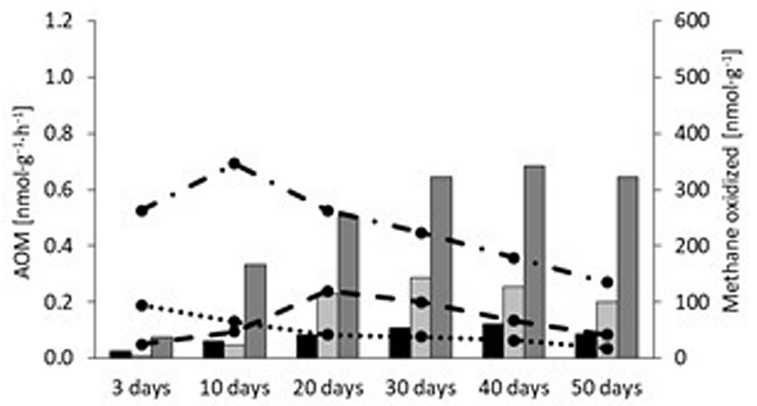

e) $10-15 \mathrm{~cm} ;{ }^{13} \mathrm{CH}_{4}$

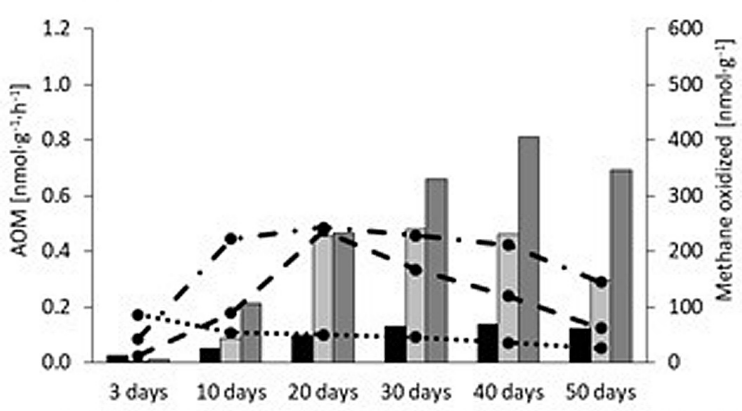

b) $0.5 \mathrm{~cm} ;{ }^{13} \mathrm{CH}_{4}+\mathrm{NO}_{3}$.

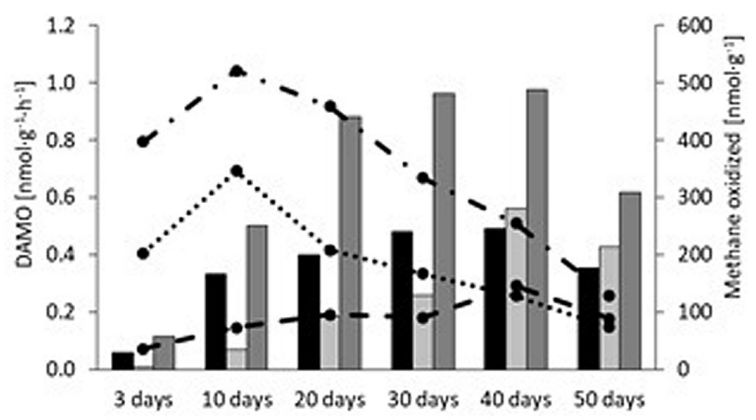

d) $5-10 \mathrm{~cm} ;{ }^{13} \mathrm{CH}_{4}+\mathrm{NO}_{3}$.

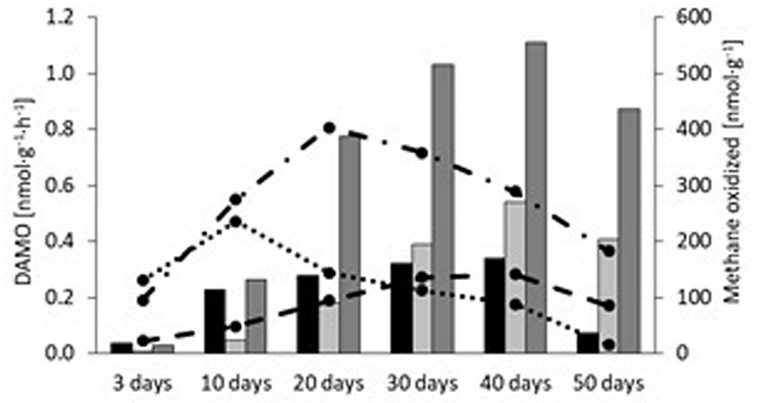

f) $10-15 \mathrm{~cm} ;{ }^{13} \mathrm{CH}_{4}+\mathrm{NO}_{3}$.

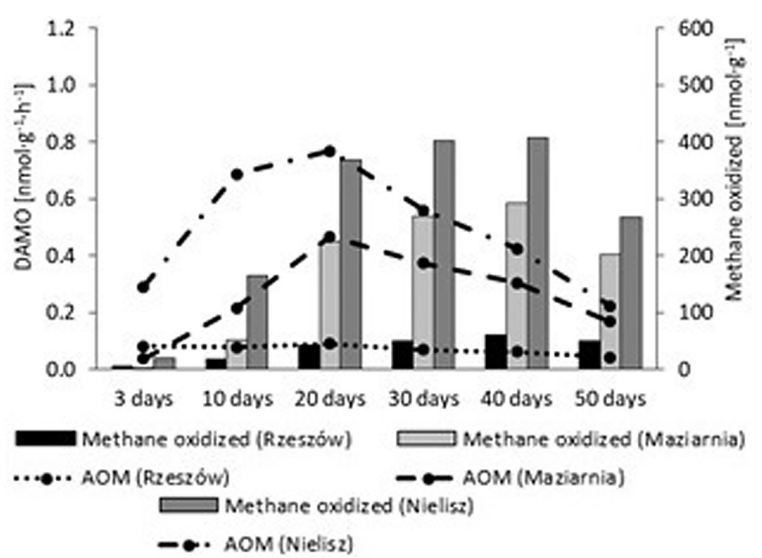

Fig. 3. Changes through time in $\mathrm{AOM}$ rate and amount of $\mathrm{CH}_{4}$ oxidised, in the course of incubations of ${ }^{13} \mathrm{CH}_{4}$ and ${ }^{13} \mathrm{CH}_{4}+\mathrm{NO}_{3}^{-}$in 0-5, 5-10 and 10-15 cm layers of sediment collected from Rzeszów, Maziarnia and Nielisz Reservoirs

existing studies relate to wetlands and peat bogs, with incubation times for sediment samples in the range from a mere 36 hours to even several weeks or months. All of our studied reservoirs yielded lower DAMO values than are present in the literature, given that 36-hour incubations of Jinchuan peatland sediments (from Jilin Province, NE China) reported on by Shi et al. [2017] were associated with average DAMO rates of 1.96-2.29 nmol $\cdot \mathrm{g}^{-1} \cdot \mathrm{h}^{-1}$; while Gupta et al. [2013] obtained the values of $5.94 \mathrm{nmol} \cdot \mathrm{g}^{-1} \cdot \mathrm{h}^{-1}$ after 21 days of incubation. Lower values $0.38 \mathrm{nmol}^{\cdot} \mathrm{g}^{-}$ ${ }^{1} \cdot \mathrm{h}^{-1}$ were recorded by Zhu et al. [2012], in relation to a 3-month incubation of sediments from the Brunssummerheide peatland.

The DAMO process has also been examined in the sediments from various sites in China (the Xiazhuhu and Xixi wetlands and a paddyfield). In these cases, rates were in the $0.01-0.23 \mathrm{nmol} \cdot \mathrm{g}^{-1} \cdot \mathrm{h}^{-1}$ range [Hu et al. 2014]. 


\section{CONCLUSIONS}

- The research provides a direct evidence of the denitrifying anaerobic methane oxidation (DAMO) process taking place in the freshwater sediments of Polish dam reservoirs. On average, irrespective of the sediment being sampled, incubation with added $\mathrm{NO}_{3}^{-}$ was associated with doubled rates of $\mathrm{CH}_{4}$ oxidation under anaerobic conditions.

- The most effective DAMO process was that characterising Nielisz Reservoir, above all sediments of its $(0-5 \mathrm{~cm})$ surface layer. In most cases, the process proved less intense in deeper layers, though no significant differences in the rates of $\mathrm{CH}_{4}$ oxidation attributable to added $\mathrm{NO}_{3}{ }^{-}$were observed in either the $10-15 \mathrm{~cm}$ layer of sediment from Rzeszów Reservoir, or the $0-5 \mathrm{~cm}$ layer from Maziarnia. In most cases, the DAMO rates peaked on day 20 of incubation.

- The availability of $\mathrm{C}$ and $\mathrm{N}$ may determine whether DAMO does or does not take place in dam-reservoir sediments. The highest contents of these in our experiment characterised the sediments from Nielisz Reservoir, and this could be seen to translate into highest DAMO rates. The converse situation also applied, in that sediments from Maziarnia Reservoir, with their lowest TOC and $\mathrm{TN}$ contents, also reported the lowest DAMO rates.

- A comparison of results with those reported for other aquatic ecosystems revealed the DAMO rates (on days 10 or 20) respectively only one-fifth or one-tenth as high in Nielisz Reservoir sediments, and in those from Rzeszów and Maziarnia Reservoirs, as in certain Chinese peat bogs. However, the rates we noted were noticeably higher than those reported from certain other wetlands in China (about twice as high in the case of Rzeszów and Maziarnia, and almost 3 times as high for Nielisz).

- As DAMO is a relatively complex matter, a better understanding of the process occurring in dam reservoirs will require further research, inter alia to recognise the DAMOassociated microorganisms and to assess the impact of abiotic factors to a greater extent.

\section{Acknowledgements}

The paper was financed by the National Science Centre Poland, via Grant No. 2017/25/B/ ST10/00981.

\section{REFERENCES}

1. Bartoszek L. 2019. Degradacja zbiorników wodnych małej retencji - uwarunkowania, nasilenie, możliwości chemicznej rekultywacji. Oficyna Wydawnicza Politechniki Rzeszowskiej, Rzeszów.

2. Bhattacharjee A.S., Motlagh A.M., Jetten M.S., Goel R. 2016. Methane dependent denitrificationfrom ecosystem to laboratory-scale enrichment for engineering applications. Water Res. 99, 244-252.

3. Broman E. 2013. Observation of methanogenesis and potential iron-dependent anaerobic oxidation of methane in old lake sediments, a study of two boreal forest lakes.

4. Chen J., Zhou Z.C., Gu J.D. 2014. Occurrence and diversity of nitrite-dependent anaerobic methane oxidation bacteria in the sediments of the South China Sea revealed by amplification of both $16 \mathrm{~S}$ rRNA and pmoA genes. Appl. Microbiol. Biotechnol. 98 (12), 5685-5696.

5. Deutzmann J.S., Stief P., Brandes J., Schink B. 2014. Anaerobic methane oxidation coupled to denitrification is the dominant methane sink in a deep lake. PNAS, 111 (51), 18273-18278.

6. Fan L., Shahbaz M., Ge T., Wu J., Dippold M., Thiel V., Kuzyakov Y., Dorodnikov M. 2019. To shake or not to shake: 13C-based evidence on anaerobic methane oxidation in paddy soil. Soil Biology and Biochemistry, 133, 146-154.

7. Griffith S.M., Schnitzer M. 1975. Analytical characteristics of humic and fiilvic acids extracted from tropical volcanic soils. Soil Sei. Soc. Am. Proc., 39: 861-867.

8. Gruca-Rokosz R. 2015. Dynamika węglowych gazów cieplarnianych w zbiornikach zaporowych - mechanizmy produkcji, emisja do atmosfery. Oficyna Wydawnicza Politechniki Rzeszowskiej, 1-132.

9. Gupta V. 2011. Anaerobic Oxidation of Methane in Northern Peatland, Department of Geography University of Toronto.

10. Gupta V., Smemo K.A., Yavitt J., Fowle D.A., Branfireun B.A., Basiliko N. 2013. Stable isotopes reveal widespread anaerobic methane oxidation across latitude and peatland type. Environ Sci Technol 47: 8273-8279.

11. Holmer M., Wildish D., Hargrave B. 2005. Organic Enrichment from Marine Finfish Aquaculture and Effects on Sediment Biogeochemical Processes. Hdb. Env. Chem., 5: 181-206, DOI 10.1007/ b136010. 
12. Hu B.L., Shen L.D., Lian X., Zhu Q., Liu S., Huang Q., He Z.F., Geng S., Cheng D.Q., Lou L.P., Xu Z.Y., Zheng P., He Y.F. 2014. Evidence for nitritedependent anaerobic methane oxidation as a previously overlooked microbial methane sink in wetlands. PANS 111(12), 4495-4500.

13. Islas-Lima S., Thalasso F., Gómez-Hernandez J. 2004. Evidence of anoxic methane oxidation coupled to denitrification. Water Research, 38(1), 13-16.

14. Jiang L., Hu Z., Wang Y., Ru D., Li J., Fan J. 2018. Effect of trace elements on the development of co-cultured nitrite-dependent anaerobic methane oxidation and methanogenic bacteria consortium. Bioresource Technology, 268, 190-196.

15. Knittel K., Boetius A. 2009. Anaerobic oxidation of methane: progress with an unknown process. Annu. Rev. Microbiol., 63, 311-334.

16. Koszelnik, P., Tomaszek, J.A. 2002. Loading of the Rzeszów reservoir with biogenic elements - mass balance. Environment Protection Engineering. 28(1), 99-106.

17. Li W., Lu P., Chai F., Zhang L., Han X., Zhang D. 2018. Long-term nitrate removal through methanedependent denitrification microorganisms in sequencing batch reactors fed with only nitrate and methane. AMB Express, 8(1):108.

18. Ma R., Hu Z., Zhang J., Ma H., Jiang L., Ru D. 2017. Reduction of greenhouse gases emissions during anoxic wastewater treatment by strengthening nitrite-dependent anaerobic methane oxidation process. Bioresource Technology, 235, 211-218.

19. Norði K., Thamdrup B. 2014. Nitrate-dependent anaerobic methane oxidation in a freshwater sediment. Geochim. Cosmochim. Acta, 132, 141-150.
20. Ostrowska A. Gawliński S., Szczubiałka Z. 1991. Metody analizy i oceny właściwości gleb i roślin. Instytut Ochrony Środowiska, Warszawa.

21. Raghoebarsing A.A., Pol A., van de Pas-Schoonen K.T., Smolders A.J., Ettwig K.F., Rijpstra W.I., Schouten S., Damsté J.S., Op den Camp H.J., Jetten M.S., Strous M. 2006. A microbial consortium couples anaerobic methane oxidation to denitrification. Nature, 440(7086), 918-921.

22. Shi Y. et al. 2017. Using $13 \mathrm{C}$ isotopes to explore denitrification-dependent anaerobic methane oxidation in a paddy-peatland. Sci. Rep. 7, 40848, doi:10.1038/srep40848.

23. Viollier E., Inglett P.W., Hunter K., Roychoudhury A.N., Van Cappellen P. 2000. The ferrozine method revisited: $\mathrm{Fe}(\mathrm{II}) / \mathrm{Fe}$ (III) determination in natural waters, Applied Geochemistry 15, 785-790.

24. Yu H., Kashima H., Regan J. M., Hussain A., Elbeshbishy E., Lee H.-S. 2017. Kinetic study on anaerobic oxidation of methane coupled to denitrification. Enzyme and Microbial Technology, 104, 47-55.

25.Zimmermann C.F., Keefe C. W., Bashe J. 1997. Determination of carbon and nitrogen in sediments and particulates/coastal waters using elemental analysis. Method 440.0. NER Laboratory, USEPA, Cincinnati, Ohio, http://www.epa.gov/nerlcwww/ m440_0.pdf.

26. Zhu G.B., Zhou L.L., Wang Y., Wang S.Y., Guo J.H., Long X.E., Sun X.B., Jiang B., Hou Q.Y., Jetten M.S.M., Yin C.Q. 2015. Biogeographical distribution of deni-trifying anaerobic methane oxidizing bacteria in Chinese wetland ecosystems. Environ. Microbiol. Rep. 7, 128-138. 